\title{
A model study of global mercury deposition from biomass burning
}

\author{
Francesco De Simone, ${ }^{\dagger}$ Sergio Cinnirella, ${ }^{\dagger}$ Christian N. Gencarelli, ${ }^{\dagger}$ Xin Yang, ${ }^{\ddagger}$ \\ Ian M. Hedgecock, ${ }^{*, \dagger}$ and Nicola Pirrone \\ CNR-Institute of Atmospheric Pollution Research, Division of Rende, \\ UNICAL-Polifunzionale, 87036 Rende, Italy, British Antarctic Survey, Cambridge, United \\ Kingdom, and CNR-Institute of Atmospheric Pollution Research, Area della Ricerca di \\ Roma 1, Via Salaria km 29,300, Monterotondo, 00015 Rome, Italy \\ E-mail: i.hedgecock@iia.cnr.it \\ Phone: +39 0984 493213. Fax: +390984 493215
}

${ }^{*}$ To whom correspondence should be addressed

${ }^{\dagger}$ CNR-Institute of Atmospheric Pollution Research, Division of Rende, UNICAL-Polifunzionale, 87036 Rende, Italy

${ }^{\ddagger}$ British Antarctic Survey, Cambridge, United Kingdom

${ }^{\top}$ CNR-Institute of Atmospheric Pollution Research, Area della Ricerca di Roma 1, Via Salaria km 29,300, Monterotondo, 00015 Rome, Italy 
were considered. The greatest uncertainties in the total $\mathrm{Hg}$ deposition were found to be associated with the $\mathrm{Hg} / \mathrm{CO}$ enhancement ratio and the emission inventory employed. Deposition flux distributions proved to be more sensitive to the emission inventory and the oxidation mechanism chosen, than all the other model parameterizations. Over $75 \%$ of $\mathrm{Hg}$ emitted from biomass burning is deposited to the world's oceans, with the highest fluxes predicted in the North Atlantic and the highest total deposition in the North Pacific. The net effect of biomass burning is to liberate $\mathrm{Hg}$ from lower latitudes and disperse it towards higher latitudes where it is eventually deposited.

\section{Introduction}

Mercury pollution is a global threat to human and ecosystem health, since its elemental form (Gaseous Elemental Mercury $(\mathrm{GEM})$ or $\mathrm{Hg}_{(\mathrm{g})}^{0}$ ), which makes up the major part of atmospheric emissions and re-emissions, can be transported far away from its emission source, (natural or anthropogenic, AMAP/UNEP ${ }^{1}$, Driscoll et al. ${ }^{2}$, Pirrone and Mason ${ }^{3}$ ). Due to increased interest in trying to constrain the global budget of $\mathrm{Hg}$ as it cycles between environmental compartments, increased attention has also been given to Biomass Burning (BB) emissions ${ }^{4-6}$. Friedli et al. ${ }^{6}$ estimated $\mathrm{Hg}$ emissions from BB by combining outputs from global carbon emission models with $\mathrm{Hg}$ enhancement ratios and found that globally $675( \pm 240) \mathrm{Mg} \mathrm{yr}^{-1}$, averaged over the period 1997-2006, is emitted from BB. As this figure is approximately one third of the yearly anthropogenic emissions of $\mathrm{Hg}$ to the atmosphere, it is clear that $\mathrm{BB}$ plays an important role in the $\mathrm{Hg}$ biogeochemical cycle. As controls on anthropogenic $\mathrm{Hg}$ emissions become stricter, proportionally the role of BB will increase, possibly substantially if the instances and extent of wildfires increases in a changing climate. It should also be noted that the location of $\mathrm{Hg}$ emissions from $\mathrm{BB}$ is very different from the location of anthropogenic emissions, with the exception of artisanal and small scale gold mining. Mercury from BB is almost all emitted $\mathrm{as}_{\mathrm{Hg}_{(\mathrm{g})}^{0}}^{0}$, with a small fraction associated with the soot from the fires ${ }^{7}$. Elemental mercury has an estimated lifetime of between 8 
months and 1 year ${ }^{2,8,9}$ and therefore can be deposited to ecosystems very distant from fire locations.

Atmospheric $\mathrm{Hg}_{(\mathrm{g})}^{0}$ can be oxidized to $\mathrm{Hg}_{(\mathrm{g})}^{\mathrm{II}}$, which is subsequently removed by both wet and dry deposition. A part of the $\mathrm{Hg}^{\mathrm{II}}$ that is deposited may be methylated within ecosystems and it is this form of $\mathrm{Hg}$ which can enter the food web and is toxic to living organisms. The recent Minamata Convention (http://www.mercuryconvention.org/) is aimed at reducing the anthropogenic impact on the global $\mathrm{Hg}$ biogeochemical cycle ${ }^{10}$. However, the natural $\mathrm{Hg}$ cycle is already significantly perturbed; it is estimated that there is five times the $\mathrm{Hg}$ in the present day atmosphere than was present in pre-industrial times ${ }^{2,11}$. The legacy of past emissions will most likely continue to influence the global biogeochemical cycle of $\mathrm{Hg}$ for decades to come ${ }^{12}$, and fires will play an important role in the continued cycling of $\mathrm{Hg}$ between environmental compartments. The primary objective of the study is to simulate the magnitude and geographical location of the $\mathrm{Hg}$ deposition flux that result from BB. Three recent BB inventories, FINNv1.0 ${ }^{13}$, GFEDv3.1 ${ }^{14}$ and GFASv1. $0^{15}$, referred to simply as FINN, GFED and GFAS hereafter, have been used to simulate $\mathrm{Hg}$ emissions from fires over the period 2006-2010. Hg emissions have been calculated as a function of CO emissions and the deposition flux distribution of $\mathrm{Hg}$ from $\mathrm{BB}$ has been simulated, using the global on-line chemical transport Hg model ECHMERIT ${ }^{16,17}$.

\section{Methodology}

\subsection{The Global Biomass Burning Inventories}

The details of the three inventories used, FINN, GFAS, and GFED and how they were compiled can be found in the literature ${ }^{13-15}$. All three inventories are based on the imagery obtained from the MODIS instruments on-board the NASA Terra and Aqua satellites; however they differ in the way in which the data are filtered or processed. GFED makes use of the burned area retrieval, FINN uses an active fire data product, while GFAS uses fire 
radiative power retrievals (the algorithm for which is based on active fire detection). Further differences in the inventories concern the land cover maps used, and the details concerning fuel load and fuel consumption. A detailed comparison and description of the inventories can be found in Andela et al. ${ }^{18}$.

Over the period 2003-2011 three inventories agree fairly well on the annual average CO emissions ${ }^{18}$. The inventories identify the same regional BB hot spots caused by tropical deforestation in South America, fires in African savannas, forest fires in South-East Asia and seasonal wildfires in Northern Hemisphere boreal regions. However, the regional differences in CO emissions between FINN, GFAS and GFED are substantial. GFAS has the highest values for areas with low burning intensity such as dry savannas. Conversely for high burning intensity fires, GFED has higher emissions. The different approaches in compiling the inventories is apparent from the relatively high emission estimate of GFAS and FINN in some areas of the world (Africa, South-East Asia and northern Brazil), whereas GFED is tuned particularly to capture large scale deforestation in central Brazil. GFED thus has higher emissions in the Southern Hemisphere than FINN and GFAS. For boreal forests GFAS and GFED emission estimates are considerably higher than FINN, see Andela et al. ${ }^{18}$.

The GFAS and GFED inventories were obtained from the Emissions of Atmospheric Compounds and Compilation of Ancillary Data (ECCAD) Global Emissions InitiAtive (GEIA) portal $^{19}$, while the FINN inventory was obtained from the Atmospheric Chemistry Division of National Center for Atmospheric Research $(\mathrm{NCAR})^{20}$. For the purpose of model validation the most recent anthropogenic Hg emission inventory from AMAP/UNEP (reference year 2010) was used ${ }^{1}$, as described in the SI.

\section{$2.2 \quad$ Model set-up}

The global Hg chemical transport model ECHMERIT ${ }^{16,17}$ is based on the fifth generation General Circulation Model ECHAM5 ${ }^{21,22}$. ECHMERIT was run using T42 horizontal resolution (roughly $2.8^{\circ}$ by $2.8^{\circ}$ at the equator) and 19 vertical levels up to $10 \mathrm{hPa}$. The increase 
in atmospheric $\mathrm{Hg}$ concentration resulting from BB were estimated as in Friedli et al. ${ }^{6}$, using an Enhancement Ratio (ER), defined as,

$\mathrm{ER}=\Delta[\mathrm{Hg}] / \Delta[\mathrm{CO}]$

where $\Delta[\mathrm{Hg}]$ is the sum of all $\mathrm{Hg}$ species in excess of background, and $\Delta[\mathrm{CO}]$ is the difference between the plume and background $\mathrm{CO}$ concentration ${ }^{6}$. The global average ER (ER $\left.{ }_{a v}\right)$ reported by Friedli et al. ${ }^{6}$ is $1.54 \times 10^{-7}$. This value was used in most of the simulations, however a number of simulations were run in which the $\mathrm{ER}_{a v}$ was substituted by biome specific ERs as described in the SI. The GFAS and GFED emissions were mapped on the ECHMERIT T42 grid using the mass conserving remapping tool included in the Climate Data Operators $(\mathrm{CDO})^{23}$. The NCAR ACD Fortran pre-processor program, Fire_Emis, was used to interpolate the FINN inventory on to the ECHMERIT grid ${ }^{24}$. The monthly average emissions were calculated for the FINN and GFAS inventories to be compatible with the GFED inventory.

With the exception of the simulations performed for model validation purposes, all simulations were performed using $\mathrm{Hg}$ emissions from BB only.

\subsection{The simulations performed}

Base case simulations used the $\mathrm{O}_{3} / \mathrm{OH}$ oxidation mechanism, however there is some uncertainty over the atmospheric $\mathrm{Hg}$ oxidation pathway ${ }^{25-27}$, therefore simulations were performed using a Br based oxidation mechanism to assess how the oxidation mechanism influences the deposition flux fields. Further simulations were performed introducing the BB emissions into different model levels, and combinations of levels. Five year simulations (2006-2010) were performed to investigate long-term differences between the inventories, while single year simulations were performed to investigate how deposition patterns varied from year to year. In the case of the single year simulations, since these were aimed at assessing the direct deposition of $\mathrm{Hg}$, the mechanism by which a fraction of deposited $\mathrm{Hg}$ is rapidly re-emitted from terrestrial, snow/ice and water surfaces ${ }^{28}$ was switched off, in all other simulations 
re-emission was included. Single year simulations were continued beyond 12 months without further emissions until at least $95 \%$ of the emitted $\mathrm{Hg}$ had been deposited. This took a further 9 to 12 months. Finally, simulations to investigate the differences in emission and deposition fields when using biome/land-cover based ERs were performed. A summary of the simulations performed can be found in Table S1.

\section{Results}

Although the primary aim of this study is to identify the areas most impacted by Hg emissions from $\mathrm{BB}$, and to see how greatly these differ from one BB inventory to another, the first simulations were performed using $\mathrm{Hg}$ emissions from all sources. The runs were performed for the year 2010, using each BB inventory for the Base mechanism, and GFED for the $\mathrm{Br}$ oxidation mechanism. GFED was also used for simulations using a fixed lifetime against oxidation ("pseudo" oxidation mechanism). The results from these simulations were compared to available measurement data, and a statistical summary of the comparison for gas phase $\mathrm{Hg}$ and for $\mathrm{Hg}$ wet deposition can be found in table 1. Maps of the comparisons are included in the SI in figures S1- S3.

Table 1: Comparison of the Base, $\mathrm{Br}$ and fixed lifetime simulations with global observations for 2010

\begin{tabular}{ccccccc} 
& & FINN & GFAS & GFED & GFED & GFED \\
& & Base & Base & Base & Br-Oxdn & 12-m fixed \\
\hline \multirow{2}{*}{ TGM } & Intercept & 0.34 & 0.31 & 0.34 & 0.18 & 0.34 \\
& Slope & 0.68 & 0.69 & 0.67 & 0.72 & 0.70 \\
& Pearson's r & 0.77 & 0.78 & 0.77 & 0.75 & 0.76 \\
& NRMSE(\%) & 14.6 & 14.4 & 14.3 & 16.7 & 15.5 \\
\hline \multirow{2}{*}{ Wet Dep } & Intercept & 9.26 & 9.05 & 9.11 & 10.4 & 7.15 \\
& Slope & 0.32 & 0.31 & 0.31 & 0.22 & 0.19 \\
& Pearson's r & 0.21 & 0.21 & 0.21 & 0.14 & 0.17 \\
& NRMSE(\%) & 19.1 & 18.6 & 18.8 & 19.6 & 13.9 \\
\hline
\end{tabular}

The comparison between the different model versions and observations all yield similar 
results, which are reasonable for Total Gaseous Mercury (TGM, the sum of gas phase elemental and oxidized $\mathrm{Hg}$ species), and less good for $\mathrm{Hg}$ wet deposition. Interestingly simply assuming a fixed atmospheric lifetime for $\mathrm{Hg}$ does not give results that are significantly worse than when a more detailed chemical mechanism is employed. However it should be pointed out that for the year 2010 almost all the observations are from the northern hemisphere, and this may not be the case when southern hemisphere sites are taken into account. (Currently the Global Mercury Observation System project is performing $\mathrm{Hg}$ monitoring at a number of sites in the southern hemisphere (www.gmos.eu)).

\subsection{Geographical distribution and seasonality of emissions}

The temporal and spatial distribution of the $\mathrm{Hg}$ emissions is dictated by the distribution of $\mathrm{CO}$ emissions because of the way they have been calculated. The differences between the inventories, in terms of CO emissions, are described elsewhere ${ }^{13-15,18,29}$.

Although the annual average $\mathrm{Hg}$ emitted between 2006-2010 is similar: 678, 603 and $600 \mathrm{Mg}$ for FINN, GFAS and GFED respectively, there are significant interannual differences and noticeable variations in the latitudinal distribution (see Figure 1).

The highest year to year variability is seen in the GFED inventory. While the FINN and GFED inventories have similar temporal profiles and are reasonably correlated $(\mathrm{r}=0.9)$. The GFAS inventory shows a markedly different temporal profile, Figure 1 (a) $(r=0.2$ and 0.5, with FINN and GFED respectively). The decreasing trend in emissions over time seen in the GFAS inventory is also at odds with the other two inventories.

The latitudinal profiles of the emissions, for the period 2006-2010, while similar, do have noticeable differences (Figure 1(c)). The GFED inventory has significantly higher emissions at around $10^{\circ} \mathrm{S}\left(6.4 \mathrm{~g} \mathrm{~km}^{-2} \mathrm{y}^{-1}\right)$, whereas the FINN inventory shows a much higher peak at around $20^{\circ} \mathrm{N}\left(4.2 \mathrm{~g} \mathrm{~km}^{-2} \mathrm{y}^{-1}\right)$. The FINN inventory also lacks the peaks at $7^{\circ} \mathrm{N}$ and at $65^{\circ} \mathrm{N}$ which are evident in the GFAS and GFED inventories. In terms of the latitudinal profile 

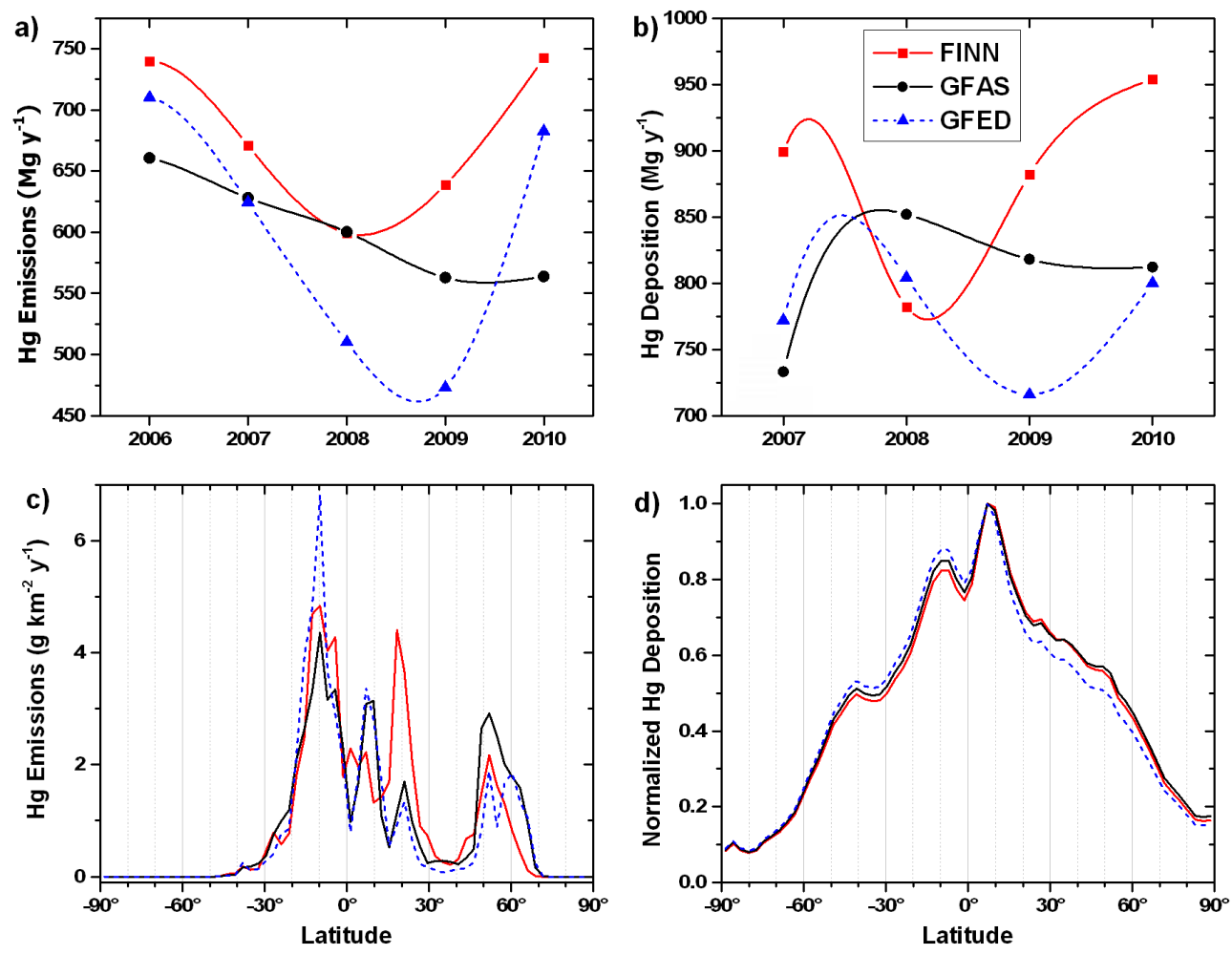

Figure 1: Annual trends and averaged latitudinal profiles of mercury emissions ((a) and (c)) and deposition ((b) and (d)). Figure (b) excludes 2006 due to low re-emissions, see section 3.2 .1 

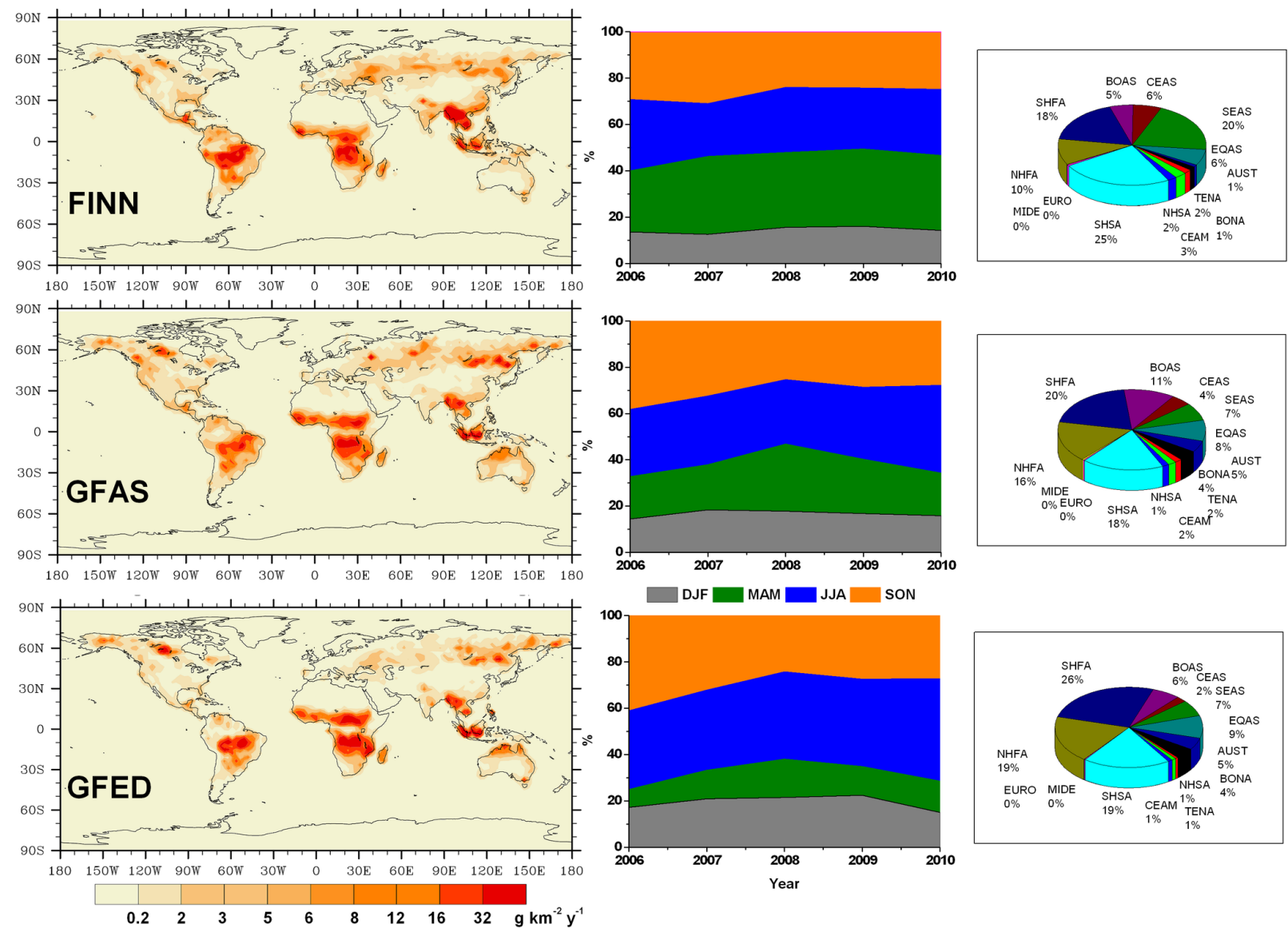

Figure 2: Geographical (left), seasonal (center, DJF - December January February, MAM March April May etc.) and regional (right) distribution of mercury emissions. Annual averages over the 2006-2010 period. The regions are, following the nomenclature used in van der Werf et al. ${ }^{14}$, (Boreal North America (BONA), Temperate North America (TENA), Central America (CEAM), Northern Hemisphere South America (NHSA), Southern Hemisphere South America (SHSA), Europe (EURO), Middle East (MIDE), Northern Hemisphere Africa (NHAF), Southern Hemisphere Africa (SHAF), Boreal Asia (BOAS), Central Asia (CEAS), Southeast Asia (SEAS), Equatorial Asia (EQAS) and Australia (AUST) 


\section{$3.2 \quad \mathrm{Hg}$ deposition}

\subsubsection{Five year simulations}

Figure 3 shows the geographical distribution of the annual total deposition (wet plus dry) due to $\mathrm{BB}$ averaged over the last four years of the 5 year simulation period, (to avoid the first year where re-emission is lower). Not surprisingly, high emissions combined with high precipitation downwind of emission source regions gives rise to high deposition fluxes. Figure 3 also shows that while $\mathrm{BB}$ emissions are terrestrial, most of the $\mathrm{Hg}$ deposition occurs over the oceans. The yearly $\mathrm{Hg}$ deposition totals using each inventory follow the emission totals (but also include deposition of re-remitted $\mathrm{Hg}$ ), (see figures 1(a) and 1(b)). The emissions latitudinal profile have well defined peaks and a distinct cut-off at the southern and northern limits of vegetation (Fig. 1(c)). The deposition profile, due to the lifetime of $\mathrm{Hg}$ in the atmosphere, shows far less pronounced peaks, a broader profile, and never reaches zero, at any latitude, Fig. 1(d). Looking at the southern hemisphere, almost all emissions are between the equator and $30^{\circ} \mathrm{S}$, even at $50^{\circ} \mathrm{S}$ the $\mathrm{Hg}$ deposition is still $40 \%$ of that seen in the high $\mathrm{Hg}$ deposition regions. This latitudinal distribution of the $\mathrm{Hg}$ is almost independent of the BB emissions inventory used, indicating that atmospheric transport determines to a great extent the $\mathrm{Hg}$ deposition flux distribution.

Another way to illustrate the importance of atmospheric transport on the simulated deposition fields is to compare the spatial correlation $(\mathrm{R})$ of the emission and the deposition fields, Table 2. The values reported were calculated using the horizontal pattern correlation method $^{30,31}$. The highest correlation for the emission inventories is found between GFAS and GFED $(\mathrm{R}=0.68)$, the lowest between FINN and GFED $(\mathrm{R}=0.38)$. The value of $\mathrm{R}$ varies from year to year (Table 2), reflecting differences in the approaches used to compile the inventories, which are discussed by Andela et al. ${ }^{18}$. Higher spatial correlations (R very close to 1) are found for the simulated $\mathrm{Hg}$ deposition fields, due to the effect of the $\mathrm{Hg}_{(\mathrm{g})}^{0}$ atmospheric lifetime, and hence transport, which smooths the variations seen in the emissions. 

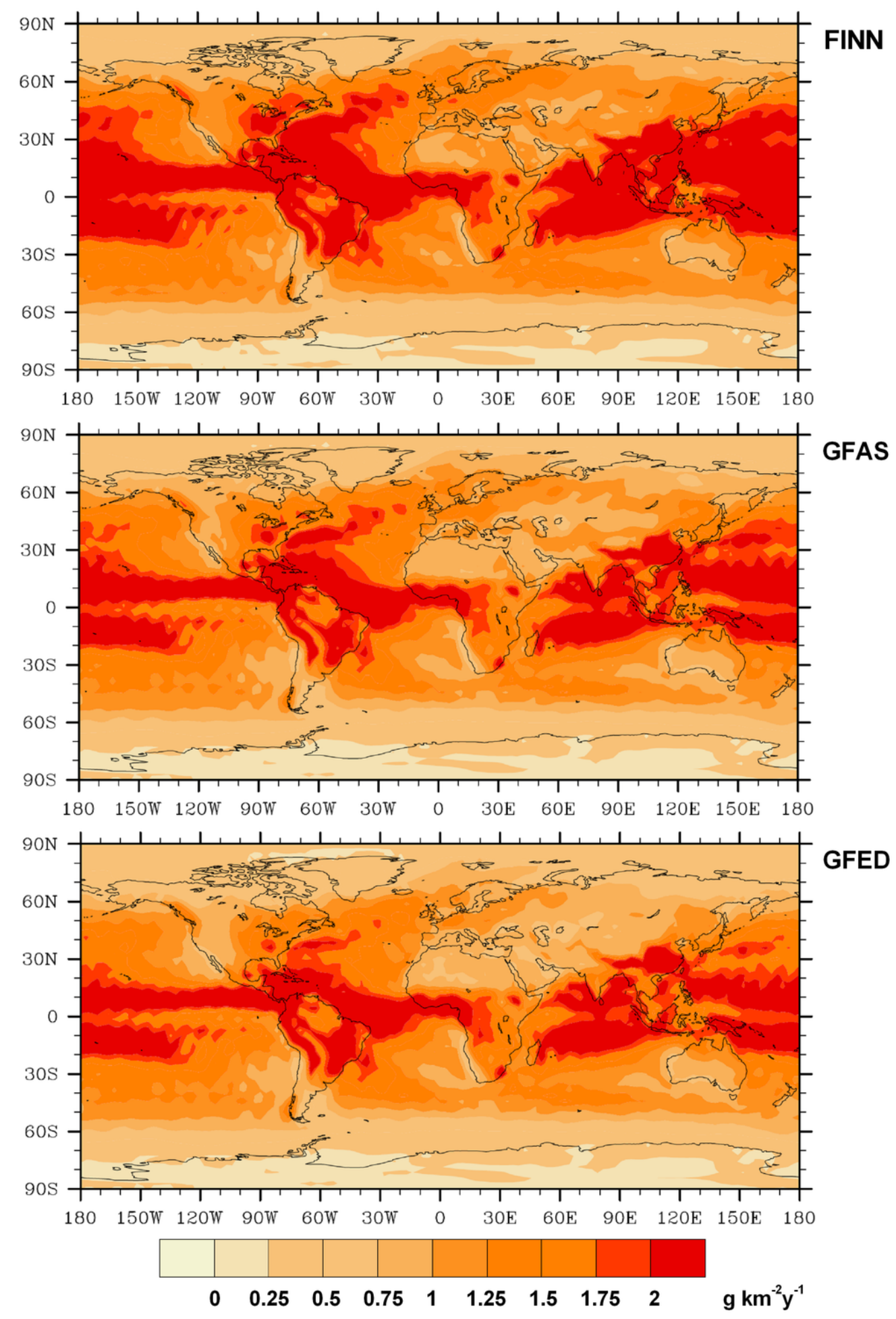

Figure 3: Geographical distribution of the total mercury deposition (wet + dry) that result from BB. Annual averages over the 2007-2010 period. 
Table 2: Spatial correlations (R) between the emissions inventories and the simulated deposition fields

\begin{tabular}{ccccccc} 
Year & FINN-GFAS & $\begin{array}{r}\text { Emissions } \\
\text { FINN-GFED }\end{array}$ & GFAS-GFED & FINN-GFAS & FINN-GFesition & GFAS-GFED \\
\hline 2006 & 0.47 & 0.33 & 0.82 & 1.00 & 0.97 & 0.98 \\
2007 & 0.42 & 0.35 & 0.66 & 1.00 & 0.98 & 0.99 \\
2008 & 0.30 & 0.31 & 0.56 & 0.99 & 0.99 & 0.99 \\
2009 & 0.29 & 0.24 & 0.47 & 0.99 & 0.99 & 0.99 \\
2010 & 0.31 & 0.37 & 0.46 & 0.99 & 0.99 & 0.99 \\
\hline $2006-10$ & 0.42 & 0.38 & 0.68 & 0.99 & 0.98 & 0.99 \\
\hline
\end{tabular}

The net effect of $\mathrm{BB}$ in tropical regions is essentially to cycle $\mathrm{Hg}$ from the tropics to mid-latitudes and to a lesser extent to high latitudes (see Figure S4). Northern boreal BB directly impacts mid- and high latitudes.

\subsection{Overall and yearly deposition comparison}

To compare the deposition fields simulated using the three inventories, maps of agreement which highlight similarities and differences in geographically resolved datasets can be used. Model cells in which the $\mathrm{Hg}$ deposition was greater than the average plus one standard deviation $(\mu+\sigma)$ were identified for each BB inventory simulation. These cells were mapped to see how consistent the extremes of the deposition distribution is between the simulations. The detailed pseudo-language algorithm used to generate such maps is presented in the SI. Figure 4 shows all of the areas where the deposition is greater than $\mu+\sigma$, for the 5 year (Base) simulations. The color of the cells denotes the level of agreement between the inventories. The high $\mathrm{Hg}$ deposition regions on which all the inventories agree represents roughly $15 \%$ of the Earth's surface, and as the map makes quite clear, most of these regions are over the tropical and northern oceans. The map (Figure 4) shows the agreement between the FINN and GFAS simulations (gray plus orange cells), and there are relatively few cells where these inventories are the only ones to predict high Hg deposition (red and yellow cells). In contrast the simulations performed using the GFED inventory show a difference in the 


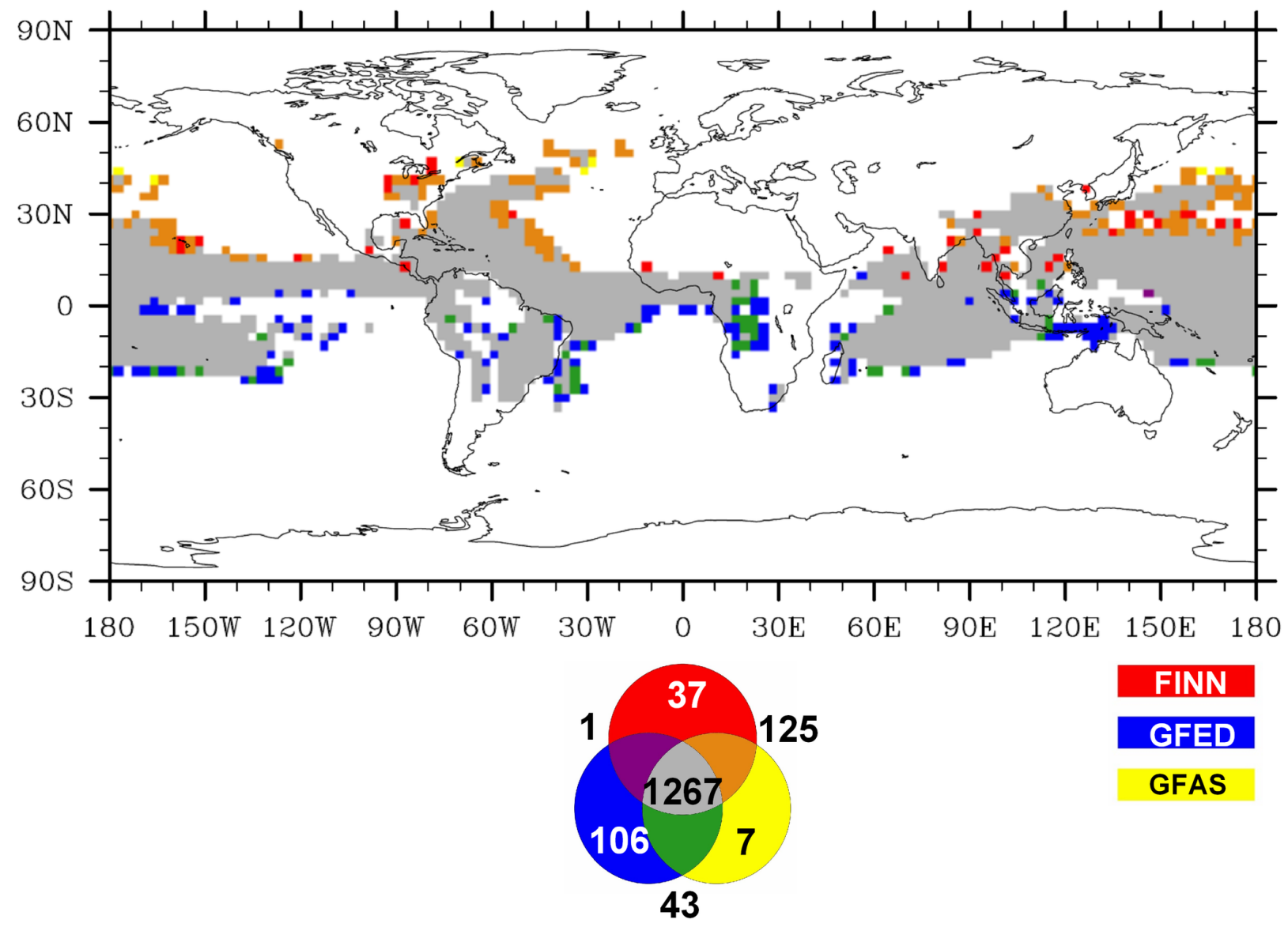

Figure 4: Agreement map of $\mathrm{Hg}$ deposition fields obtained from GFAS, GFED and FINN for the five year simulation. The map shows the areas where deposition is $>\mu+\sigma$. Primary colors (red, blue and yellow) represent non-agreement between inventories, green, purple and brown indicate agreement between two of the inventories and gray indicates agreement between all three. The numbers refer to the number of cells in common between the simulations using the different inventories (The whole globe is represented by 8192 cells) 
prediction of regions of high $\mathrm{Hg}$ deposition, and particularly in the southern hemisphere, and to the southern edge of the region where all three inventories agree.

All of the inventories have an emission peak at roughly $10^{\circ} \mathrm{S}$ but while that of FINN and GFAS is $\approx 4.5-5 \mathrm{~g} \mathrm{~km}^{-2} \mathrm{y}^{-1}$, that in GFED is $\approx 7 \mathrm{~g} \mathrm{~km}^{-2} \mathrm{y}^{-1}$. This accounts for the large number of cells in the southern hemisphere where the simulation performed with GFED predicts high $\mathrm{Hg}$ deposition values. Interestingly, at around $20^{\circ} \mathrm{N}$ there is a peak in the FINN inventory that is more than twice as high as the corresponding values in GFED and GFAS. Given the relatively few areas where only the simulations with the FINN inventory predict high $\mathrm{Hg}$ deposition, this peak in emissions seems to affect the results relatively little, suggesting that at certain latitudes, differences (in magnitude and precise location) in the inventories have a negligible influence on the simulation results. (See Figure 1(c)). However in the case with the simulation performed using GFED, the magnitude and location of the emissions are much more important. Anthropogenic emissions in the southern hemisphere are low compared to the northern hemisphere, therefore the contribution to atmospheric $\mathrm{Hg}$ from $\mathrm{BB}$ is relatively more important in this region. From these results it appears that precision in the magnitude and location of $\mathrm{BB}$ emissions in the southern hemisphere is particularly necessary.

ECHMERIT has also been run for individual years (2006-2010) using each of the emission inventories. As above for the 5 year simulation, agreement maps for deposition greater than $\mu+\sigma$ for each inventory have been prepared to compare the results from each inventory for each year. The simulations predict the same total global area of high deposition $(\approx 14$ 16\%) each year, and also that these areas are consistent from year to year. While the FINN and GFAS inventories give similar results, the GFED inventory consistently predicts higher deposition in the Southern hemisphere. This is true for each of the single year simulations as it was for the 5 year simulation. Since the major BB source in south of the Equator is the Amazon, this may well reflects the fact that GFED is "tuned" to capture large scale deforestation in this region ${ }^{18}$ (Figure S5). 


\subsection{Sensitivity Studies}

The emission inventories used for these studies have their own intrinsic uncertainties ${ }^{13-15,32}$. Biome specific emission factors, assumptions concerning the oxidation mechanism and the atmospheric lifetime of $\mathrm{Hg}$, and also the height (model layer) at which the $\mathrm{BB}$ emissions are introduced into the atmosphere are all potential sources of uncertainty. Some of these uncertainties are common to all BB studies, such as plume modeling, injection height, diurnal variation of fire intensity, fire areas and enhancement ratios ${ }^{6,33}$. To investigate the impact of the parameterizations on the $\mathrm{Hg}$ deposition fields a number of sensitivity runs were performed (see Table S1).

\subsubsection{Enhancement ratio}

The most critical of all the assumptions made concerning $\mathrm{Hg}$ emissions from $\mathrm{BB}$ is the Enhancement Ratio (ER). Using $\mathrm{ER}_{a v}$ makes the modeling studies themselves more simple, and also avoids making a series of interconnected assumptions concerning ERs, vegetation types and their distribution, each of which could potentially introduce further errors into the model. The two major uncertainties when attempting to use a biome dependent approach to $\mathrm{Hg}$ emissions from $\mathrm{BB}$ are knowledge of the distribution of vegetation types, and the ER associated with a given type of vegetation, which may vary with location. There have been relatively few determinations of $\mathrm{Hg}$ concentrations in $\mathrm{BB}$ plumes for specific vegetation types ${ }^{6}$. The ERs reported vary significantly for most vegetation types and can differ by more than an order of magnitude for a given biome. This is most likely due to a combination of factors including soil $\mathrm{Hg}$ content, fire intensity and fire location. Two biome specific ER simulations were performed using the GFED inventory. The first, $\mathrm{ER}_{\text {coarse, }}$ was calculated using the vegetation type characterization published in Friedli et al. ${ }^{6}$, whereas the second set, $\mathrm{ER}_{\text {fine }}$, was obtained following a more detailed characterization methodology as described in the SI. Using $\mathrm{ER}_{a v}$ (leads to $\mathrm{Hg}$ emissions from BB of $599.4 \pm 104.6 \mathrm{Mg}$, whereas $\mathrm{ER}_{\text {coarse }}$ and $\mathrm{ER}_{\text {fine }}$ give $447.9 \pm 81.2 \mathrm{Mg}$ and $301.9 \pm 114.0 \mathrm{Mg}$ respectively, see Table S2. Not only does 
the emission total change with ER calculation method, but so does interannual variability (from 17\% to 38\%) and the spatial correlation pattern (see R in Table S2). Nearly all of the difference is due to the distinction between savanna and tropical forest in Africa. The ER for savanna, at $0.28 \times 10^{-7}$ is less than $20 \%$ of $\mathrm{ER}_{a v}\left(1.54 \times 10^{-7}\right)$, and even though the tropical forest ER is higher than the global average $\left(2.05 \times 10^{-7}\right)$ this does not compensate for the decrease in $\mathrm{Hg}$ emissions from the vast savanna regions of Africa. In comparison the higher ratio of forest to savanna in South America means that overall there is little change in the total $\mathrm{Hg}$ emissions for this region. The simulations using the more detailed ER estimates show a decreased spatial correlation for $\mathrm{Hg}$ deposition with respect to the simulations using an average ER, see Tables 2, 3 and S2. Although the magnitude of $\mathrm{Hg}$ emission, and therefore also the magnitude of the $\mathrm{Hg}$ deposition flux, is different using the specific ERs, the impact on the geographical distribution of the deposition is limited.

\subsubsection{Injection height}

The height at which emissions from BB are introduced into the model can have a significant impact on pollutant transport. Some recent studies have shown that boreal fire emissions can be lofted above the boundary layer ${ }^{34,35}$. A long term study of the CALIOP (Cloud-Aerosol Lidar with Orthogonal Polarization) profiles over South-Western Russia and Eastern Europe for 2006-2008 showed that as much as $50 \%$ of the BB plumes were above the boundary layer ${ }^{36}$. A detailed review of injection heights and plume rise models can be found in Ichoku et al. ${ }^{33}$. Simulations were performed in which the emissions were added to different model levels up to approximately $2000 \mathrm{~m}$. Further simulations, one in which the emissions were distributed uniformly throughout the lower levels of the model, and a second with a prescribed latitudinally dependent vertical distribution, were performed ${ }^{37,38}$. Comparing the Hg deposition patterns obtained in these experiments to the base case reveals a very high correlation, $\mathrm{R} \approx 1$, see table 3 . The atmospheric lifetime of $\mathrm{Hg}_{(\mathrm{g})}^{0}$ is the main reason for this lack of influence of the emission height on the simulated deposition fields. Similar results 
have been obtained in studies of CO plumes, where the impact of emission height on atmospheric composition is significant locally, and only has a minor influence on regions distant from the plume source ${ }^{39-41}$.

\subsubsection{Sensitivity to oxidation mechanism}

As mentioned in Section 2.2 the precise mechanism by which $\mathrm{Hg}_{(\mathrm{g})}^{0}$ is oxidized in the atmosphere is not yet certain ${ }^{25-27}$. Most models opt for a combination of $\mathrm{O}_{3} / \mathrm{OH}$, or alternatively a Br based oxidation mechanism. In either case $\mathrm{Hg}_{(\mathrm{g})}^{0}$ has an atmospheric lifetime of approximately 8 to 12 months, which is consistent with the observed difference in the hemispherical background concentrations of $\mathrm{Hg}_{(\mathrm{g})}^{0}$ (roughly $1.7 \mathrm{ng} \mathrm{m}^{-3}$ in the Northern Hemisphere and 1.2 in the southern). For 2010 simulations were performed utilizing each oxidation pathway with each BB emission inventory. Further simulations, using fixed atmospheric lifetimes against oxidation (e-folding time, see description in the SI) of 12 and 6 months were also performed. The agreement maps for the simulations are presented in figure S6.

Although the number of cells where all the inventories agree that $\mathrm{Hg}$ deposition is high does not differ greatly between the different simulations, the distribution of the 'agreement' does. This is particularly true of the tropical Atlantic; using the $\mathrm{Br}$ mechanism there is no 'high' deposition area to the west of Africa, however the 'high' deposition region in the North Atlantic reaches Iceland, which it does not in the $\mathrm{O}_{3} / \mathrm{OH}$ simulation. Again, in the $\mathrm{Br}$ simulation the 'high' deposition area reaches into the Gulf of Alaska, whereas in the $\mathrm{O}_{3} / \mathrm{OH}$ simulation the 'high' deposition regions are more closely confined to a relatively narrow latitude band between the tropics, reflecting the distribution of $\mathrm{O}_{3}$ in the troposphere. The $\mathrm{Br}$ simulation does show noticeably more areas where only the GFED inventory predicts high deposition, particularly in the Southern Ocean. This is in part due to the higher southern hemisphere emissions in GFED, but also because the period of the year when biomass burning is most prevalent in South America, July to September, coincides with low tropospheric Br concentrations, so that the emissions are transported much further in this simulation 
than in the $\mathrm{O}_{3} / \mathrm{OH}$ simulation.

The simulations using a fixed atmospheric lifetime for $\mathrm{Hg}$ give results that are more similar to the $\mathrm{Br}$ mechanism, particularly in the case of the 12 month lifetime. In neither of the two simulations is the high deposition distribution as closely confined to the area between the tropics as in the $\mathrm{O}_{3} / \mathrm{OH}$ case. In all the simulations most $\mathrm{Hg}$ deposition from $\mathrm{BB}$ emissions is deposited to the oceans. Clearly more monitoring sites in the Tropics would help immensely to understand more fully the importance of $\mathrm{BB} \mathrm{Hg}$ emissions on oceanic $\mathrm{Hg}$ deposition. Table S3 summarises the simulated Hg deposition to the world's ocean basins. The table includes the simulated deposition totals calculated using full atmospheric emissions (natural, anthropogenic and BB) for the two oxidation mechanisms for 2010.

\subsubsection{Uncertainty in the Deposition fields}

The Hg deposition fields obtained in this study vary and it is not immediately clear where and to what extent the results agree. In order to examine the 'ensemble' of results, rather than just averaging the full set of simulations, the model output has been tested against the Base run (GFED, $\mathrm{O}_{3} / \mathrm{OH}$, global ER, year 2010) to ascertain the probability that the deposition fields belong to the same distribution. This then permits those results which differ the most to be identified. This form of 'inspected' ensemble was recently described by Solazzo and Galmarini $^{42}$ for a multi-model ensemble. The non-parametric Kolmogorov-Smirnov twosample test has been used to examine the results of the sensitivity tests performed using the GFED inventory. The test was repeated with the model output obtained using the FINN and GFAS inventories with the $\mathrm{O}_{3} / \mathrm{OH}$ and $\mathrm{Br}$ oxidation mechanisms and with the 12 month pseudo-oxidation approach. The results of the test are shown in Table 3. A value of Prob $_{K S-t e s t} \leq 0.05$ indicates that it is improbable that the simulated $\mathrm{Hg}$ deposition fields belong to the same distribution. The height at which the emissions are introduced into the model, and the first Enhancement Ratio variation $\left(\mathrm{ER}_{\text {coarse }}\right)$ make very little difference to the output results. The most important factors influencing the output fields are the inventory 
Table 3: Correlations and probabilities that the sensitivity run $\mathrm{Hg}$ deposition fields belong to the same distribution as the GFED 2010 simulation deposition field, and comparison with FINN and GFAS

\begin{tabular}{|c|c|c|c|c|c|c|c|}
\hline & & & $\mathrm{m}$ & & $-\mathrm{OH}$ & & $3 r$ \\
\hline RUN & Sensitivity assessment & $\mathrm{R}$ & $P_{K S}$ & $\mathrm{R}$ & $P_{K S}$ & $\mathrm{R}$ & $P_{K S}$ \\
\hline Emissions & Vertically distributed & 1.00 & 1.00 & 1.00 & 1.00 & 1.00 & 1.00 \\
\hline Emissions & Inj. into ind. levels & 1.00 & 1.00 & 1.00 & 1.00 & 1.00 & 1.00 \\
\hline Oxidation mech. & $\mathrm{O}_{3} / \mathrm{OH}$ & 0.91 & $<0.05$ & - & - & 0.81 & $<0.05$ \\
\hline Oxidation mech. & $\mathrm{Br}$ & 0.96 & $<0.05$ & 0.81 & $<0.05$ & - & - \\
\hline Lifetime $\operatorname{Hg}(0)$ & 12 months & - & - & 0.91 & $<0.05$ & 0.96 & $<0.05$ \\
\hline Lifetime $\mathrm{Hg}(0)$ & 6 months & 0.99 & 0.41 & 0.97 & $<0.05$ & 0.89 & $<0.05$ \\
\hline Enhancement Ratio & $\mathrm{ER}_{\text {coarse }}$ & 1.00 & 0.99 & 1.00 & 1.00 & 1.00 & 1.00 \\
\hline Enhancement Ratio & $\mathrm{ER}_{\text {fine }}$ & 0.99 & 0.52 & 1.00 & 0.17 & 1.00 & 0.10 \\
\hline & FINN 2010 emissions & 0.97 & $<0.05$ & 1.00 & $<0.05$ & 0.98 & $<0.05$ \\
\hline & GFAS 2010 emissions & 0.97 & $<0.05$ & 1.00 & 0.08 & 0.99 & 0.09 \\
\hline
\end{tabular}

and the oxidation mechanism. The second variation of the Enhancement Ratio $\left(\mathrm{ER}_{\text {fine }}\right)$ described in Section 3.4.1 also results in noticeably different deposition fields even if the hypothesis that the model output belongs to the same distribution as the Base case cannot be rejected, Prob $_{K S-t e s t}=0.17$ and 0.10, with the $\mathrm{O}_{3} / \mathrm{OH}$ and $\mathrm{Br}$ oxidation mechanisms respectively. This is also true for the GFAS inventory Prob $_{K S-t e s t}=0.08$ and 0.09 , however these values indicate that the probability of belonging to the same distribution is low. The results from the three inventories, and also the ER2 sensitivity run, with both the $\mathrm{O}_{3} / \mathrm{OH}$ and Br oxidation mechanisms have therefore been averaged to obtain an 'ensemble' deposition field, which is illustrated in figure 5. The figure makes it evident that however much the simulated deposition fields differ, the regions most influenced by $\mathrm{Hg}$ deposition from biomass burning are the tropical areas of the oceans, the North Atlantic and the North Pacific.

\section{Discussion}

Just over $75 \%$ of the $\mathrm{Hg}$ released by BB is deposited to the world's oceans and seas. As is well known, human exposure to methylmercury (the most toxic form) occurs predominantly through fish consumption. $\mathrm{Hg}^{\mathrm{II}}$ deposited to the ocean may be reduced and re-emitted 


$$
\begin{aligned}
& \text { Total Dep : } 580.45 \pm 130.01 \mathrm{Mg} \mathrm{y}^{-1} \\
& \text { Flux : } 0.97 \pm 0.47 \mathrm{~g} \mathrm{~km}^{2} \mathrm{y}^{-1}
\end{aligned}
$$
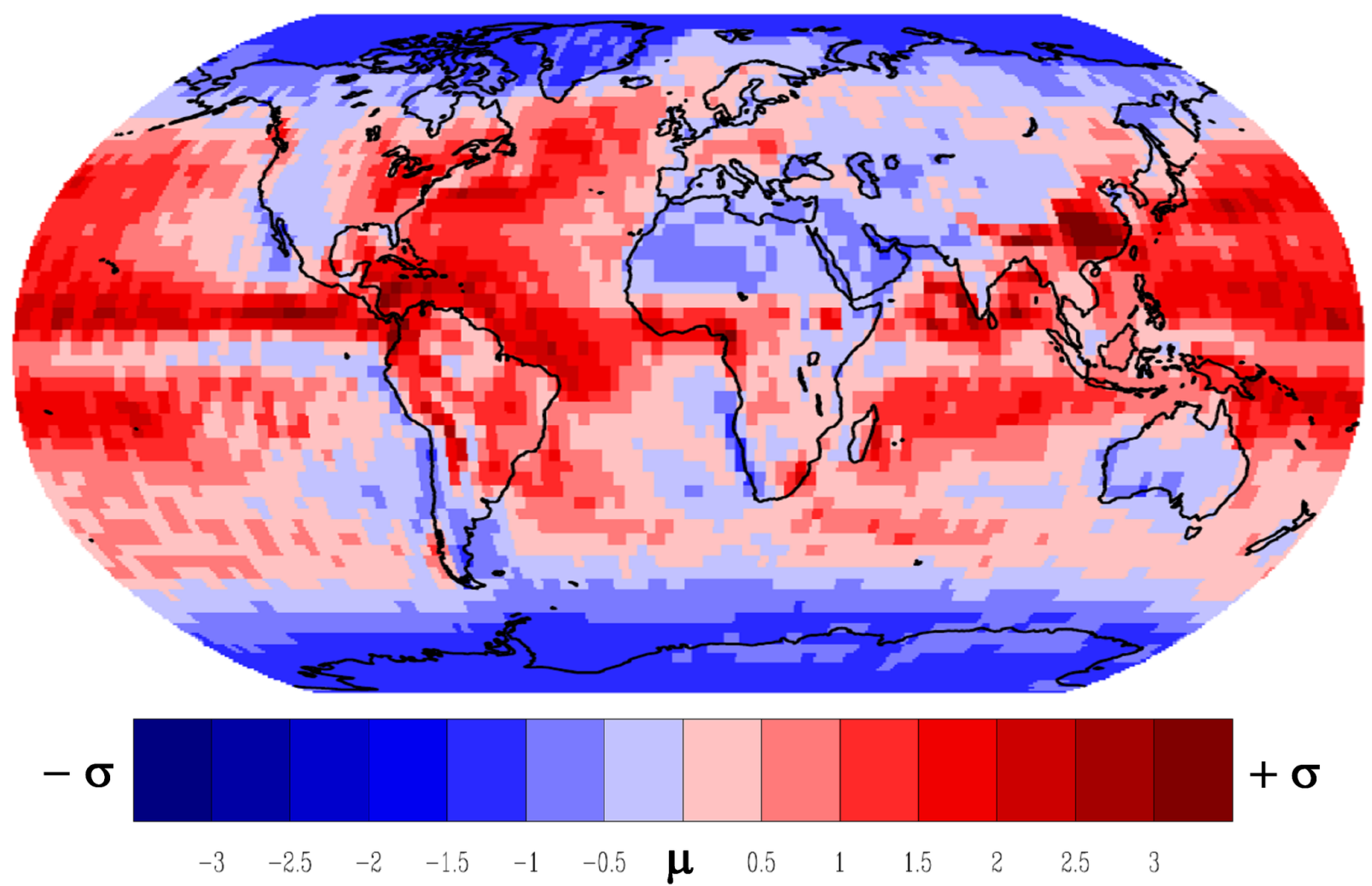

Figure 5: Geographical distribution of the probability density function of the total Hg deposition obtained from an inspected ensemble of simulations for the year 2010. Total deposition is illustrated in terms of the average $(\mu)$ and standard deviation $\sigma$ of the ensemble. 
from the sea surface, but a part can be methylated in surface or subsurface waters, where it can enter the food web ${ }^{2,43,44}$. The maximum deposition fluxes in the individual oceanic regions, are very similar for all the $\mathrm{BB}$ inventories. From the results obtained from the five year runs it was found that the North Atlantic has the highest peak deposition flux value at $21 \mathrm{~g} \mathrm{~km}^{-2}$, followed by the North Pacific and Indian Oceans at $\approx 20 \mathrm{~g} \mathrm{~km}^{-2}$. The maximum $\mathrm{Hg}$ deposition flux in the Arctic reaches $7 \mathrm{~g} \mathrm{~km}^{-2}$, higher than the Mediterranean $\left(6 \mathrm{~g} \mathrm{~km}^{-2}\right)$ and the Southern Ocean $\left(3 \mathrm{~g} \mathrm{~km}^{-2}\right)$. The total calculated emissions of $\mathrm{Hg}$ from BB are similar for all three inventories used in this study, although there are differences in their geographical distribution. GFED has a higher proportion of emissions in the southern hemisphere (Figure 1c) in comparison to the other two inventories and this is also visible in the deposition fields ((Figure 1d). However the lifetime of $\mathrm{Hg}_{(\mathrm{g})}^{0}$ is such that the differences in the spatial distribution of the emissions is far less evident in the simulated deposition fields. GFED is a slight exception as the distribution, relatively to the other two inventories has a higher proportion of emissions in the southern hemisphere (Figure 1c) this is visible also in the deposition fields (Figure 1d). One effect of BB is to emit $\mathrm{Hg}$ from lower latitudes for eventual deposition at higher latitudes, in both hemispheres. The presence of higher latitude boreal forests in the Northern Hemisphere does mean that the Arctic is more impacted than the Antarctic by $\mathrm{Hg}$ deposition resulting from BB. The highest $\mathrm{Hg}$ deposition fluxes are found in the North Atlantic, while the the greatest total $\mathrm{Hg}$ deposition is to the North Pacific. The oxidation mechanism and the choice of emission inventory have the greatest influence on the spatial distribution of the Hg deposition fields. The factor which most influences the total calculated $\mathrm{Hg}$ emission from $\mathrm{BB}$ is the enhancement ratio. More biome specific $\mathrm{Hg} / \mathrm{CO}$ enhancement ratios are needed to better constrain the magnitude of $\mathrm{Hg}$ emissions from BB. In order to build a bottom-up inventory it would be necessary to perform measurements of $\mathrm{Hg}$ and $\mathrm{CO}$ released by $\mathrm{BB}$ and also ideally to distinguish between the same biomes on different continents. As the number of $\mathrm{Hg}$ monitoring sites around the world increases, intermittent information will become more abundant as stations will at times be downwind 
of BB plumes, however a more targeted approach addressing, tropical, savanna and boreal ecosystems would be far better. Biomass burning will continue to play a role in the cycling of $\mathrm{Hg}$, and legacy $\mathrm{Hg}$ particularly, for a long time to come. As the Minamata Convention comes into force and anthropogenic emissions begin to be curbed, the role of BB in cycling $\mathrm{Hg}$ from the tropics to higher latitudes, and particularly in transferring $\mathrm{Hg}$ from terrestrial reservoirs to the oceans will become more important. Understanding the recycling of legacy $\mathrm{Hg}$ is particularly important in the assessment of the response times of ecosystems to changes in anthropogenic emissions, especially should the frequency and scale of BB increase as the climate changes.

\section{Acknowledgement}

We are grateful to Sebastian Rast and his staff at the Max Planck Institute for Meteorology in Hamburg, Germany for the distribution of their software ECHAM5 and for providing the access to the processed ERA-INTERIM data. The research was performed in the framework of the EU project GMOS (FP7 - 265113). The authors would also like to thank the three anonymous referees whose helpful suggestions and comments contributed much to improving the original manuscript.

\section{Supporting Information Available}

Tables summarizing the simulations performed with ECHMERIT, the spatial correlation (R) for different ERs, annual Hg deposition to the major oceans basins. Figures illustrating the Base, $\mathrm{Br}$ and fixed lifetime model results, and agreement maps of $\mathrm{Hg}$ deposition. Sections describing the pseudo-language algorithm used to generate Agreement Maps, the calculation of ERs, and the oxidation mechanisms implemented in the model. This material is available free of charge via the Internet at http://pubs.acs.org/. 


\section{References}

(1) AMAP/UNEP, Technical Background Report for the Global Mercury Assessment 2013; Arctic Monitoring and Assessment Programme, Oslo, Norway/UNEP ChemicalsBranch, Geneva, Switzerland, 2013.

(2) Driscoll, C. T.; Mason, R. P.; Chan, H. M.; Jacob, D. J.; Pirrone, N. Mercury as a Global Pollutant: Sources, Pathways, and Effects. Environ. Sci. Technol. 2013, 47, 4967-4983.

(3) Pirrone, N., Mason, R., Eds. Mercury Fate and Transport in the Global Atmosphere: Emissions, Measurements and Models; Springer US, 2009.

(4) Cinnirella, S.; Pirrone, N. Spatial and temporal distributions of mercury emissions from forest fires in Mediterranean region and Russian federation. Atmos. Environ. 2006, 40, $7346-7361$.

(5) Wiedinmyer, C.; Friedli, H. Mercury Emission Estimates from Fires: An Initial Inventory for the United States. Environ. Sci. Technol. 2007, 41, 8092-8098.

(6) Friedli, H. R.; Arellano, A. F.; Cinnirella, S.; Pirrone, N. Initial estimates of mercury emissions to the atmosphere from global biomass burning. Environ. Sci. Technol. 2009, 43, 3507-3513.

(7) Obrist, D.; Moosmüller, H.; Schürmann, R.; Chen, L.-W. A.; Kreidenweis, S. M. Particulate-phase and gaseous elemental mercury emissions during biomass combustion: Controlling factors and correlation with particulate matter emissions. Environ. Sci. Technol. 2007, 42, 721-727.

(8) Schroeder, W. H.; Munthe, J. Atmospheric mercury - An overview. Atmos. Environ. 1998, 32, $809-822$. 
(9) Holmes, C. D.; Jacob, D. J.; Corbitt, E. S.; Mao, J.; Yang, X.; Talbot, R.; Slemr, F. Global atmospheric model for mercury including oxidation by bromine atoms. Atmos. Chem. Phys. 2010, 10, 12037-12057.

(10) Selin, N. E. Global change and mercury cycling: Challenges for implementing a global mercury treaty. Environ. Toxicol. Chem. 2014, 33, 1202-1210.

(11) Streets, D. G.; Devane, M. K.; Lu, Z.; Bond, T. C.; Sunderland, E. M.; Jacob, D. J. All-Time Releases of Mercury to the Atmosphere from Human Activities. Environ. Sci. Technol. 2011, 45, 10485-10491.

(12) Amos, H. M.; Jacob, D. J.; Streets, D. G.; Sunderland, E. M. Legacy impacts of all-time anthropogenic emissions on the global mercury cycle. Global Biogeochem. Cycles 2013, 27, 410-421.

(13) Wiedinmyer, C.; Akagi, S. K.; Yokelson, R. J.; Emmons, L. K.; Al-Saadi, J. A.; Orlando, J. J.; Soja, A. J. The Fire INventory from NCAR (FINN): a high resolution global model to estimate the emissions from open burning. Geosci. Model Dev. 2011, 4, 625-641.

(14) van der Werf, G. R.; Randerson, J. T.; Giglio, L.; Collatz, G. J.; Mu, M.; Kasibhatla, P. S.; Morton, D. C.; DeFries, R. S.; Jin, Y.; van Leeuwen, T. T. Global fire emissions and the contribution of deforestation, savanna, forest, agricultural, and peat fires (1997-2009). Atmos. Chem. Phys. 2010, 10, 11707-11735.

(15) Kaiser, J. W.; Heil, A.; Andreae, M. O.; Benedetti, A.; Chubarova, N.; Jones, L.; Morcrette, J.-J.; Razinger, M.; Schultz, M. G.; Suttie, M.; van der Werf, G. R. Biomass burning emissions estimated with a global fire assimilation system based on observed fire radiative power. Biogeosciences 2012, 9, 527-554.

(16) Jung, G.; Hedgecock, I. M.; Pirrone, N. ECHMERIT v1.0 - a new global fully coupled mercury-chemistry and transport model. Geosci. Model Dev. 2009, 2, 175-195. 
(17) De Simone, F.; Gencarelli, C. N.; Hedgecock, I. M.; Pirrone, N. Global atmospheric cycle of mercury: a model study on the impact of oxidation mechanisms. Environ. Sci. Pollut. Res. 2014, 21, 4110-4123.

(18) Assessment of the Global Fire Assimilation System (GFASv1). MACC-II (Monitoring Atmospheric Composition and Climate) project, 2013; http://juser.fz-juelich.de/record/186645.

(19) Emissions of atmospheric Compounds \& Compilation of Ancillary Data (ECCAD). http://eccad.sedoo.fr/eccad_extract_interface/JSF/page_products_em.jsfdatabase.

(20) Fire Emission Factors and Emission Inventories. http://bai.acd.ucar.edu/Data/fire/.

(21) The atmospheric general circulation model ECHAM 5. PART I: Model description, MPI-Report No. 349, 2003; https://www.mpimet.mpg.de/fileadmin/publikationen/Reports/max_scirep_349.pdf.

(22) Roeckner, E.; Brokopf, R.; Esch, M.; Giorgetta, M.; Hagemann, S.; Kornblueh, L.; Manzini, E.; Schlese, U.; Schulzweida, U. Sensitivity of Simulated Climate to Horizontal and Vertical Resolution in the ECHAM5 Atmosphere Model. J. Clim. 2006, 19, 37713791.

(23) Climate Data Operators. 2014; Max-Plank Institute fur Meteorologie, 2014; https://code.zmaw.de/projects/cdo.

(24) Fire_Emis: Fortran based preprocessor for creating fire emission inputs for WRF-Chem. http://www.acd.ucar.edu/wrf-chem/.

(25) Hynes, A. J.; Donohoue, D. L.; Goodsite, M. E.; Hedgecock, I. M. In Mercury Fate and Transport in the Global Atmosphere: Emissions, Measurements and Models; Pirrone, N., Mason, R. P., Eds.; Springer, 2009; Chapter 14, pp 427-457. 
(26) Subir, M.; Ariya, P. A.; Dastoor, A. P. A review of uncertainties in atmospheric modeling of mercury chemistry I. Uncertainties in existing kinetic parameters - Fundamental limitations and the importance of heterogeneous chemistry. Atmos. Environ. 2011, 45, $5664-5676$.

(27) Subir, M.; Ariya, P. A.; Dastoor, A. P. A review of the sources of uncertainties in atmospheric mercury modeling II. Mercury surface and heterogeneous chemistry - A missing link. Atmos. Environ. 2012, 46, 1 - 10.

(28) Selin, N. E.; Jacob, D. J.; Yantosca, R. M.; Strode, S.; Jaeglé, L.; Sunderland, E. M. Global 3-D land-ocean-atmosphere model for mercury: Present-day versus preindustrial cycles and anthropogenic enrichment factors for deposition. Global Biogeochem. Cycles 2008, 22, GB2011.

(29) Stroppiana, D.; Brivio, P. A.; Grégoire, J.-M.; Liousse, C.; Guillaume, B.; Granier, C.; Mieville, A.; Chin, M.; Pétron, G. Comparison of global inventories of CO emissions from biomass burning derived from remotely sensed data. Atmos. Chem. Phys. 2010, 10, 12173-12189.

(30) Santer, B. D.; Taylor, K. E.; Wigley, T. M.; Penner, J. E.; Jones, P. D.; Cubasch, U. Towards the detection and attribution of an anthropogenic effect on climate. Clim. Dyn. 1995, 12, 77-100.

(31) Santer, B. D.; Taylor, K. E.; Wigley, T. M. L.; Johns, T. C.; Jones, P. D.; Karoly, D. J.; Mitchell, J. F. B.; Oort, A. H.; Penner, J. E.; Ramaswamy, V.; Schwarzkopf, M. D.; Stouffer, R. J.; Tett, S. A search for human influences on the thermal structure of the atmosphere. Nature 1996, 382, 39-46.

(32) van Leeuwen, T. T.; Peters, W.; Krol, M. C.; van der Werf, G. R. Dynamic biomass burning emission factors and their impact on atmospheric $\mathrm{CO}$ mixing ratios. J. Geophys. Res. Atmos. 2013, 118, 6797-6815. 
(33) Ichoku, C.; Kahn, R.; Chin, M. Satellite contributions to the quantitative characterization of biomass burning for climate modeling. Atmos. Res. 2012, 111, 1-28.

(34) Lapina, K.; Honrath, R. E.; Owen, R. C.; Val Martín, M.; Hyer, E. J.; Fialho, P. Late summer changes in burning conditions in the boreal regions and their implications for NOx and CO emissions from boreal fires. J. Geophys. Res. Atmos. 2008, 113, D11304-.

(35) Val Martin, M.; Logan, J. A.; Kahn, R. A.; Leung, F.-Y.; Nelson, D. L.; Diner, D. J. Smoke injection heights from fires in North America: analysis of 5 years of satellite observations. Atmos. Chem. Phys. 2010, 10, 1491-1510.

(36) Amiridis, V.; Giannakaki, E.; Balis, D. S.; Gerasopoulos, E.; Pytharoulis, I.; Zanis, P.; Kazadzis, S.; Melas, D.; Zerefos, C. Smoke injection heights from agricultural burning in Eastern Europe as seen by CALIPSO. Atmos. Chem. Phys. 2010, 10, 11567-11576.

(37) Williams, J. E.; van Weele, M.; van Velthoven, P. F. J.; Scheele, M. P.; Liousse, C.; van der Werf, G. R. The Impact of Uncertainties in African Biomass Burning emission estimates on modeling global air quality, long range transport and tropospheric chemical lifetimes. Atmosphere 2012, 3, 132-163.

(38) Dentener, F. et al. Emissions of primary aerosol and precursor gases in the years 2000 and 1750 prescribed data-sets for AeroCom. Atmos. Chem. Phys. 2006, 6, 4321-4344.

(39) Leung, F.-Y. T.; Logan, J. A.; Park, R.; Hyer, E.; Kasischke, E.; Streets, D.; Yurganov, L. Impacts of enhanced biomass burning in the boreal forests in 1998 on tropospheric chemistry and the sensitivity of model results to the injection height of emissions. J. Geophys. Res. Atmos. 2007, 112, D10313-.

(40) Guan, H.; Chatfield, R. B.; Freitas, S. R.; Bergstrom, R. W.; Longo, K. M. Modeling the effect of plume-rise on the transport of carbon monoxide over Africa with NCAR CAM. Atmos. Chem. Phys. 2008, 8, 6801-6812. 
(41) Jian, Y.; Fu, T.-M. Injection heights of springtime biomass-burning plumes over peninsular Southeast Asia and their impacts on long-range pollutant transport. Atmos. Chem. Phys. 2014, 14, 3977-3989.

(42) Solazzo, E.; Galmarini, S. A science-based use of ensembles of opportunities for assessment and scenario study: a re-analysis of HTAP-1 ensemble. Atmos. Chem. Phys. 2015, 15, 2535-2544.

(43) Sunderland, E. M.; Krabbenhoft, D. P.; Moreau, J. W.; Strode, S. A.; Landing, W. M. Mercury sources, distribution, and bioavailability in the North Pacific Ocean: Insights from data and models. Global Biogeochem. Cycles 2009, 23, GB2010-.

(44) Blum, J. D.; Popp, B. N.; Drazen, J. C.; Anela Choy, C.; Johnson, M. W. Methylmercury production below the mixed layer in the North Pacific Ocean. Nat. Geosci. 2013, $6,879-884$. 